\title{
Nitric Oxide Activates Granule-Associated DNase in Human Monocytes
}

\author{
Rubén Pío, María J . López-Zabalza, Ana Rouzaut, \\ Esteban Santiago, and Natalia López-Moratalla ${ }^{1}$ \\ Department of Biochemistry, University of Navarra, 31080 Pamplona, Spain
}

Activated and differentiated human monocytes with a CD14 ${ }^{+} \mathrm{CD} 16^{+}$phenotype were found to contain a DNase activity associated with secretion granules. Activated cells were obtained from patients with autoimmune diseases. Activation and differentiation of monocytes were also achieved after incubation of PBMC from healthy subjects with protein A (SpA) or immunopotentiating peptides. DNase activity corresponded to a 66-kDa protein, similar to that described in granules from $\mathbf{T}$ lymphocytes, active preferentially on double-strand DNA. DNA fragmentation activity increased when NO donors were present; the activity was higher in the presence of $\mathrm{Ca}^{2+}$, and at low $\mathrm{pH}$ values. The $\mathrm{Ca}^{2+}$-dependent activity was inhibited by $\mathrm{Zn}^{2+}$. NOdependent activity was additive with that of $\mathrm{Ca}^{2+}$ dependent and it was not inhibited by $\mathrm{Zn}^{2+}$. Dithiothreitol did not modify the effect of NO on DNase activity. Incubation of PBMC in the presence of NMLA, an inhibitor of NO synthases, decreased this DNase activity. Data reported clearly suggest a regulatory role of NO in granule-associated DNase activity. ๑ 1998 Academic Press

Key Words: nitric oxide; DNase activity; human monocytes; cytotoxic monocytes.

Human peripheral blood monocytes can act as antigen-presenting cells or be effector cells of the

\footnotetext{
${ }^{1}$ To whom correspondence should be addressed. Fax: (+ 34 948) 4256 49. E-mail: natalialm@unav.es.
}

immune system and are engaged in host defense against infections and tumors. Monocytes display a wide range of functional and morphological phenotypes; their functions are highly dependent on stimuli from the environment and are characterized by the expression of particular cell surface antigens (1). Although most monocytes are $\mathrm{CD} 14^{++}$, there exists also a small subpopulation in which the expression of CD14 is rather low and is at the same time CD16 positive (2). The $\mathrm{CD} 14^{+} \mathrm{CD} 16^{+}$phenotype is characteristic of monocytes containing abundant secretion granules, and is often considered as circulating macrophages (3). Monocytes/macrophages play an important role in the defense mechanisms of the immune system, partly mediated by the cytotoxic activity of some of these cells, which secrete cytolytic molecules. These lytic substances, packed in granules, are released by exocytosis after contacting target cells (4). Reactive oxygen intermediates are involved in monocyte-mediated cytotoxicity against tumor cells; after maturation of monocytes to macrophages, these cytotoxic products become less important, and reactive nitrogen intermediates are then used in the killing of tumor cells (5). Furthermore, the importance of monocytes/macrophages in the development of the autoimmune response has been underscored. Cytokines released by infiltrating macrophages play a key role in tissue damage; secretion of monokines causes lymphocyte activation and demyelinization in multiple sclerosis (6). An alteration in the maturation of circulating mono- 
cytes is involved in the development of rheumatoid arthritis (7). Cytotoxic monocytes seem to play an important role in autoimmune thyroiditis (8) as well as in other autoimmune diseases of the connective tissue, such as rheumatoid arthritis or ankylosing spondylitis (9). Nitric oxide is a mediator in several physiological responses (10). In the immune response, mediated by monocytes/macrophages, NO controls the regulation of diverse processes, among them those of the release of cytokines (11) and the expression of HLA-DR on human monocytes (12).

We have previously described a DNase activity associated to granules of cytotoxic $T$ lymphocytes and suggested its participation in the lytic and/or apoptotic mechanisms of these cells in the immune response (13). In view of the variety of functions of NO we were prompted to study whether it had an effect on the activation of DNase as well as on the induction of the granule expression of this enzyme in cytotoxic monocytes. We report here the presence of a protein with DNase activity in cytoplasmic granules in monocytes. This activity was higher in monocytes from patients with autoimmune diseases than that of monocytes from healthy subjects, and it was associated with the $\mathrm{CD} 14^{+} \mathrm{CD} 16^{+}$monocyte subpopulation. Data obtained suggest that the increase in DNase activity induced by nitric oxide is one of the mechanisms through which NO is involved in the destructive attack displayed by monocytes/ macrophages against target cells, such as those of the organs affected in the autoimmune response.

\section{MATERIALS AND METHODS}

Subjects. All patients with clinically defined primary biliary cirrhosis (PBC), ${ }^{2}$ multiple sclerosis (MS), or Graves' disease (GD) included in this report are part of a follow-up study being carried out at the University Clinic of the University of Navarra (Spain). We studied 4 patients with PBC (female/ male: 4/0; age \pm standard deviation: $50 \pm 10$ ), 5

\footnotetext{
${ }^{2}$ Abbreviations used: PBC, primary biliary cirrhosis; MS, multiplesclerosis; GD, Graves' disease; HD, healthy donors; iNOS, inducible nitric oxide synthase; PBMC, peripheral blood mononuclear cells; FI, fragmentation index; SpA, protein A from Staphylococcus aureus; NMLA, N-methyl-L-arginine; SIN-1, 3-morpholinosydnonimine; SNAP, S-nitroso-N-acetyl-D,L-penicillamine; DTT, dithiothreitol.
}

patients with MS (3/2; $45 \pm 7), 7 \mathrm{GD}(6 / 1 ; 45 \pm 8)$, and 15 healthy donors (HD) (9/6; $37 \pm 13)$.

Peptide synthesis. Peptide Pal (NVLGAPKKLNESQAV), known to have immunomodulating properties $(14,15)$ and capable of inducing iNOS in human monocytes (12), and the immunomodulating peptide Pa2 (CLCADPYELGDDGR) from thyroid peroxidase (16) were synthesized by the solid-phase method of Merrifield (17), with the F moc modification (18).

Cell sources and cultures. Mononuclear cells were obtained from peripheral blood (PBMC) of healthy donors or patients following the technique described by Bøyum (19). Cells were incubated at $1 \times 10 \% / \mathrm{ml}$ in RPMI 1640 medium supplemented with $2.5 \%$ autol ogous serum in a $5 \% \mathrm{CO}_{2}$ humidified atmosphere. I solation and purification of monocytes were carried out taking advantage of their adherence to culture plates. After a period of $4-6 \mathrm{~h}$ at $37^{\circ} \mathrm{C}$ nonadherent cells were removed with the supernatant followed by three washes with saline solution. Adherent cells, consisting mainly of monocytes (in the case of healthy donors, approximately $90 \%$ of the cells were $\mathrm{CD}_{14}{ }^{+}$), were then carefully detached from the surface of the culture plates by gentle friction and resuspended in a small volume of saline solution.

Extraction of granule proteins. The isolation of secretion granules was carried out following the procedure of Podack et al. (20), using a Percoll density gradient after disrupting the cells with a Parr nitrogen bomb.

Detection of DNase activity. Detection of DNase activity in protein extracts was performed by the ability to degrade genomic DNA. The extracted granule proteins corresponding to monocytes obtained from $3 \times 10^{7}$ PBMC were incubated with 10 $\mu \mathrm{g}$ of protein free DNA at $37^{\circ} \mathrm{C}$ for $24 \mathrm{~h}$ in $50 \mu \mathrm{l}$ of a $50 \mathrm{mM} \mathrm{NaCl}, 10 \mathrm{mM} \mathrm{MgCl}, 1 \mathrm{mM}$ dithiothreitol (DTT), $10 \mathrm{mM}$ Tris- $\mathrm{HCl}$ autoclaved buffer, pH 7.5. Some incubations were performed without the addition of DTT. When testing at $\mathrm{pH}$ values other than 7.5, the following buffers were used: sodium acetate (pH 5), Mes (pH 6), Mops (pH 7), or Tris (pH 8), all at $10 \mathrm{mM}$ concentration. An aliquot of $20 \mu \mathrm{l}$ of the resulting mixture was applied to a $1 \%$ agarose gel, and subjected to electrophoresis at a voltage of $50 \mathrm{~V}$ 
in $1 \mathrm{mM}$ EDTA, $40 \mathrm{mM}$ Tris- $\mathrm{HCl}$ buffer, $\mathrm{pH}$ 7.5, containing $0.5 \mu \mathrm{g}$ of ethidium bromide per milliliter. Genomic DNA was obtained as described in the literature (21). To quantify and compare the results obtained in different experiments, we carried out a simple image analysis with the appropriate software (Image Master, Pharmacia), as described (13). Briefly, electrophoregrams on gels were photographed and images scanned and inverted. Each lane was divided into three sectors, using as reference a molecular weight marker (Hind III-digested $\lambda$ phage DNA, Promega). Sector A corresponded to the 23-kb first band of the marker; sector $B$ extended from the lower limit of sector $A$ to the top of the 2.3-kb band of the marker; and sector $C$ extended from the lower limit of sector $B$ to the end of the lane. The "fragmentation index" was calculated as: FI $(\%)=1 / 2$ B (\%DNA $>2.3 \mathrm{~kb})+\mathrm{C}(\% \mathrm{DNA}<2.3$ $\mathrm{kb})$. In each case, a digestion in DNase free medium was performed in parallel to calculate the spontaneous degradation which was subtracted from F.I.

DNase detection in DNA-SDS-PAGE. Protein electrophoresis was carried out following the technique of Laemmli and Favre (22). Separating gels (12\% acrylamide- bisacrylamide $37.5 / 1$ ) were prepared with the addition of $10 \mu \mathrm{g} / \mathrm{ml}$ calf thymus DNA. Protein extracts were mixed with sample loading buffer $(0.125 \mathrm{M}$ Tris- $\mathrm{HCl}$, pH 6.4, 4\% SDS, $20 \%$ glycerol, $10 \% \beta$-mercaptoethanol, and $0.01 \%$ bromophenol blue) and heated at $37^{\circ} \mathrm{C}$ for $20 \mathrm{~min}$ before being placed in the wells. Following electrophoresis, gels were washed, in order to ensure the removal of SDS and $\beta$-mercaptoethanol, three times in distilled water, once in $40 \mathrm{mM}$ Tris- $\mathrm{HCl}, \mathrm{pH} 7.6,2 \mathrm{mM}$ $\mathrm{MgCl}_{2}, 1 \mathrm{mM}$ EDTA, and twice again in distilled water. Each wash was prolonged for $10 \mathrm{~min}$. I ncubation was continued for $4 \mathrm{~h}$ in $10 \mathrm{mM}$ Tris- $\mathrm{HCl}, \mathrm{pH}$ 7.6, $50 \mathrm{mM} \mathrm{NaCl}, 1 \mathrm{mM} \mathrm{CaCl}, 10 \mathrm{mM} \mathrm{MgCl} 2,1 \mathrm{mM}$ DTT. Some experiments were also carried out in the absence of DTT. After adding ethidium bromide (1 $\mu \mathrm{g} / \mathrm{ml}$ ) to the gel incubation buffer, gels were examined under UV light and photographed. The positions of DNase activity were revealed as dark bands on a fluorescent background.

Determination of nitrite nitrate For the determination of nitrites and nitrates, spontaneous degradation products of nitric oxide, a commercial kit was used (Alexis Corp., Läufelfingen, Switzerland). Photometric measurement was carried out at 540 $\mathrm{nm}$. Assays were performed on samples containing $2 \times 10^{6}$ lymphomononuclear cells previously disrupted by means of a Parr bomb. An aliquot of the incubation medium was used as reaction blank.

Analysis of monocytesubpopulations. Phenotypic characterization of monocytes was carried out using an EPICS Profile II flow cytometer (Coulter Electronics, Hialeah, FL). Cells were incubated with CD14 antibody (Leu-M3)-FITC and CD16 antibody (Leu11a)-PE at $4^{\circ} \mathrm{C}$ for $30 \mathrm{~min}$. CD16 antigen expression was measured only on cells that costained positively for Leu-M3. The monoclonal antibodies used in this work were supplied by Becton-Dickinson (BectonDidkinson I mmunocytometry Systems, Erembodegen, Belgium). Analysis of membrane determinant coexpression using double-color combinations (fluorescein and phycoerythrin) was carried out following the manufacturer's instructions.

Statistical analysis. The values obtained were subjected to the Mann-Whitney $U$ test to compare data between groups of subjects. Correlation between DNase activity and $\mathrm{CD} 14^{+} \mathrm{CD} 16^{+}$cells was analyzed by the Spearman test. A $P$ value less than 0.05 was considered to be significant.

\section{RESULTS}

DNase activity on cytoplasmic granules in monocytes. We determined DNase activity in granules corresponding to monocytes isolated from healthy donors or patients with autoimmune diseases, as well as corresponding to monocytes from healthy donors isolated after incubation of PBMC for 5 days in the presence of peptide $\mathrm{Pal}$ or peptide $\mathrm{Pa} 2$ (30 $\mu \mathrm{g} / 10^{6}$ cells) or SpA ( $20 \mu \mathrm{g} / 10^{6}$ cells). Protein extracts from secretion granules corresponding to monocytes isolated from $3 \times 10^{7}$ PBMC in each case were incubated with protein-free genomic DNA for $24 \mathrm{~h}$. Then DNase activity was determined analyzing DNA fragmentation by electrophoresis on agarose gel. DNase activity, expressed as "fragmentation index" (FI), was higher in monocytes from patients and in peptide-activated monocytes than in those of freshly cells from healthy donors (Fig. 1).

Phenotypic characterization of monocytes. We carried out a flow cytometry analysis of monocytes 


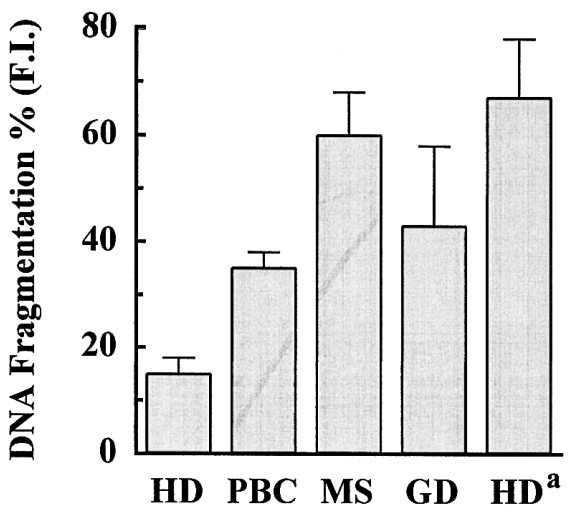

FIG. 1. DNase activity in granules from monocytes. DNase activity is expressed as "fragmentation index" (FI). Data represent the mean $\pm S D$. Values corresponding to patients were significantly different from those of healthy donors $(P<0.05)$. ${ }^{a}$ Results obtained with monocytes of healthy donors after incubation in two independent experiments with peptide Pal (30 $\mu \mathrm{g} / 10^{6}$ cells), two with peptide Pa2 ( $30 \mu \mathrm{g} / 10^{6}$ cells), and two with SpA ( $20 \mu \mathrm{g} / 10^{6}$ cells); values corresponding to cells incubated in the presence of peptides were significantly higher than those of the controls $(P<0.05)$.

from the different groups with the purpose of examining possible correlations between monocyte subpopulations and DNase activity. Two-color immunofluorescence analysis of monocytes coexpressing CD14 and CD16 was performed. Table I shows the percentage of monocytes in peripheral blood and the percentage of $\mathrm{CD}_{14}{ }^{+} \mathrm{CD} 16^{+}$cells in the monocyte population. The percentage of monocytes with this phenotype was higher in freshly obtained cells from autoimmune patients, and in cells from healthy donors after incubation of their PBMC in the presence of immunomodulating agents, than that in fresh

\section{TABLE I}

Percentage of $\mathrm{CD} 14^{++/+}$and $\mathrm{CD} 14^{+} \mathrm{CD} 16^{+}$Monocytes

\begin{tabular}{|c|c|c|}
\hline & $\mathrm{CD}_{14} 4^{++/+}$ & $\mathrm{CD} 14^{+} \mathrm{CD} 16^{+}$ \\
\hline & (\% PBMC) & $\left(\% \mathrm{CD} 14^{+}\right)$ \\
\hline Healthy donors & $11 \pm 2$ & $10 \pm 2$ \\
\hline Primary biliary cirrhosis & $10 \pm 4$ & $20 \pm 5$ \\
\hline Multiple sclerosis & $7 \pm 3$ & $32 \pm 5$ \\
\hline Graves' disease & $6 \pm 4$ & $27 \pm 4$ \\
\hline Healthy donors ${ }^{a}$ & $13 \pm 2$ & $34 \pm 4$ \\
\hline
\end{tabular}

Note Data represent the mean \pm SD.

${ }^{a}$ Results obtained in healthy donors after incubation with activating agents. See figure 1 for details.

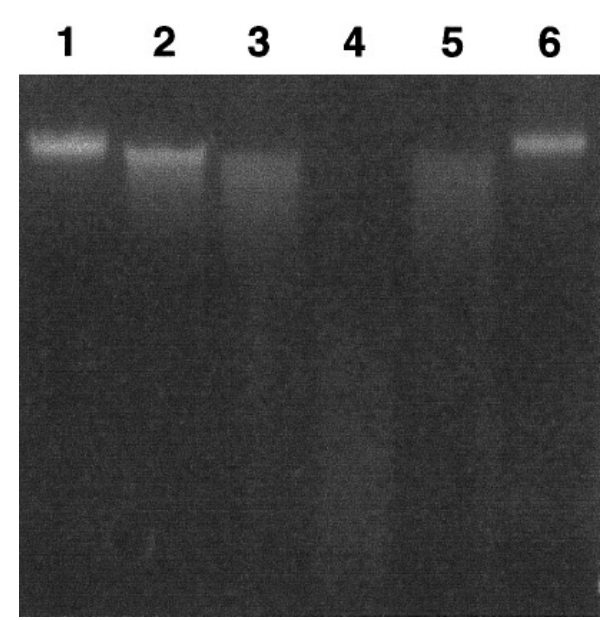

FIG. 2. Cation dependence of DNase activity. Protein extracts were incubated with genomic DNA for $12 \mathrm{~h}$ in $10 \mathrm{mM}$ Tris- $\mathrm{HCl}$, $\mathrm{pH} 7.5,10 \mathrm{mM} \mathrm{MgCl} 2,50 \mathrm{mM} \mathrm{NaCl}$ and in the presence of divalent cations at the indicated concentrations. DNA fragmentation is representative of seven independent experiments. Lane 1 , DNA incubated in the absence of protein extract and in the presence of calcium ions (1 mM); lane 2, $0.01 \mathrm{mM} \mathrm{Ca}^{2+}$; lane 3, 0.1 $\mathrm{mM} \mathrm{Ca}^{2+}$; lane 4, $1 \mathrm{mM} \mathrm{Ca}^{2+}$; Iane 5, $10 \mathrm{mM} \mathrm{Ca}^{2+}$; lane 6, $1 \mathrm{mM}$

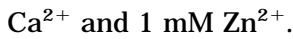

monocytes from healthy donors. We found a positive correlation between the proportion of $\mathrm{CD} 14^{+} \mathrm{CD} 16^{+}$ cells within the monocyte population and their granule associated DNase activity $(r=0.73$; $P<0.05)$.

Properties of the granule associated DNase. Properties of the DNase now found in monocytes were similar to those of the granule DNase present in T lymphocytes (13): its activity increased when $\mathrm{Ca}^{2+}$ was present in the medium at $\mathrm{pH} 7.5$ (Fig. 2); the activity was highest at $1 \mathrm{mM} \mathrm{Ca}{ }^{2+}$. The addition of $\mathrm{Zn}^{2+}$ impeded the stimulatory effect of $\mathrm{Ca}^{2+}$ ions (Fig. 2). DNase activity was also measured in the absence of calcium at $\mathrm{pH}$ values of $8,7,6$, and 5 and it was observed that the activity increased with the acidification of the medium (Fig. 3).

We studied also the effect of NO on DNase activity. Protein extracts from granules of monocytes were incubated with genomic DNA for $12 \mathrm{~h}$ in 10 $\mathrm{mM}$ Tris- $\mathrm{HCl}, \mathrm{pH} 7.5,10 \mathrm{mM} \mathrm{MgCl}_{2}, 50 \mathrm{mM} \mathrm{NaCl}$ and the corresponding concentrations of a nitric oxide donor, SIN-1 or SNAP. Figure 4 shows the results obtained corresponding to one of seven independent experiments. DNA fragmentation produced by the enzyme increased with the concentration of the NO donor. The presence of $1 \mathrm{mM} \mathrm{Zn}^{2+}$ did not 


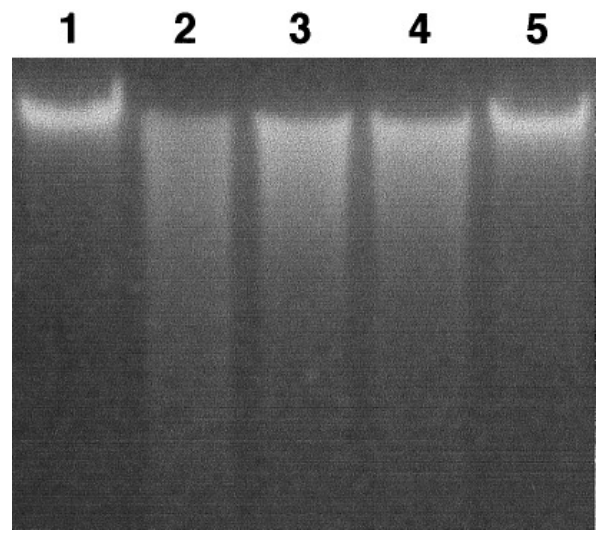

FIG. 3. Effect of pH on granule-associated DNase. Protein extracts were incubated with genomic DNA in $10 \mathrm{mM} \mathrm{MgCl}_{2}, 50$ $\mathrm{mM} \mathrm{NaCl}$, and the corresponding buffers at the indicated $\mathrm{pH}$ values. DNA fragmentation is representative of 10 independent experiments. Lane 1, DNA incubated at $\mathrm{pH} 5$ in the absence of protein extract; lanes $2,3,4$, and 5, DNA incubated with protein extracts at $\mathrm{pH} 5,6,7$, and 8 , respectively.

affect the increase in activity caused by NO. It was also observed that a further increase in activity took place, when, in addition to the NO donor, 0.1 or 1 $\mathrm{mM} \mathrm{Ca}{ }^{2+}$ was present (Fig. 5).

We considered also the possibility that the reducing agent DTT, present in the medium used to detect the DNase activity, could affect the activation of the enzyme by nitric oxide. The presence or absence of DTT did not modify the DNase activity associated with monocytic granules, when incubation mixtures contained the NO donor SIN-1 at various concentrations (Fig. 6). DNase activity was not affected either when using SIN-1 at a fixed concentration (1 mM)

\section{[SNAP] (mM)}

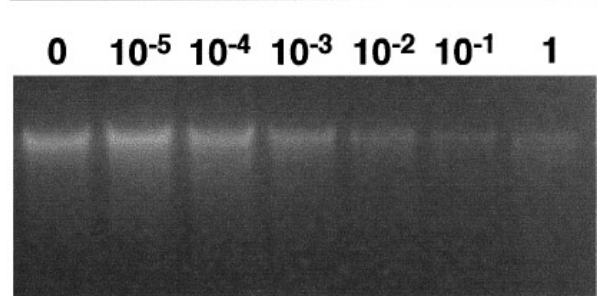

FIG. 4. Stimulation of DNase activity by NO. Protein extracts were incubated with genomic DNA for $12 \mathrm{~h}$ in $10 \mathrm{mM}$ Tris- $\mathrm{HCl}$, $\mathrm{pH}$ 7.5, $10 \mathrm{mM} \mathrm{MgCl}_{2}, 50 \mathrm{mM} \mathrm{NaCl}$, and the corresponding concentrations of SNAP. Electrophoregram reflecting DNase activity extracted from granules present in monocytes is representative of seven independent experiments.
A

B

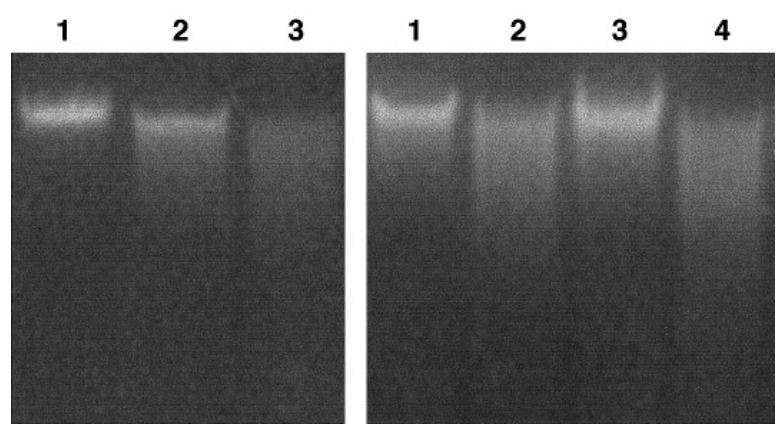

FIG. 5. Effect of divalent cations on NO-dependent DNase activity. Protein extracts were incubated with genomic DNA for $12 \mathrm{~h}$ in $10 \mathrm{mM}$ Tris- $\mathrm{HCl}$, pH 7.5, $10 \mathrm{mM} \mathrm{MgCl}$, $50 \mathrm{mM} \mathrm{NaCl}$, and the corresponding concentrations of $\mathrm{SIN}-1$ and divalent cations. Electrophoresis is representative of three independent experiments. (A) Lane 1, DNA incubated in the absence of cations and SIN-1; lane 2, $1 \mathrm{mM} \mathrm{Ca}^{2+}$; lane 3, $1 \mathrm{mM} \mathrm{Ca}^{2+}$ and $1 \mathrm{mM} \mathrm{SIN-1.}$ (B) Lane 1, DNA incubated in the absence of cations and SIN-1;

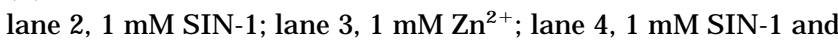

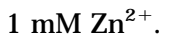

and different DTT concentrations (Fig. 6).

In order to discard spontaneous DNA hydrolysis due to incubation conditions, genomic DNA was also incubated in the presence of the different buffers, cations, and NO donors and in the absence of protein extracts containing the enzyme.

Finally, we determined the molecular weight of the protein having DNase activity using the SDSPAGE technique (23). Protein extracts from secretion granules of monocytes were separated by SDSPAGE in gels containing DNA. Under UV light, proteins with DNase activity appear as dark bands

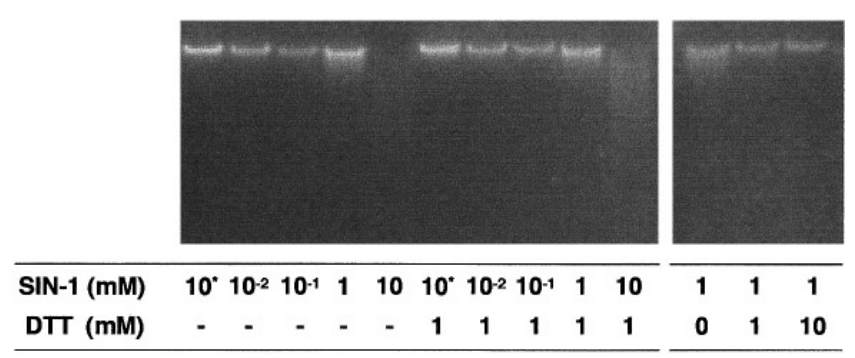

FIG. 6. Lack of effect of the reducing agent DTT on NOdependent DNase activity. Protein extracts were incubated with genomic DNA in $10 \mathrm{mM}$ Tris- $\mathrm{HCl}, \mathrm{pH} 7.5,10 \mathrm{mM} \mathrm{MgCl} 2,50 \mathrm{mM}$ $\mathrm{NaCl}$, and the indicated concentrations of DTT and SIN-1 for $12 \mathrm{~h}$. Electrophoresis is representative of two independent experiments. *DNA incubated in buffer without protein extract. 


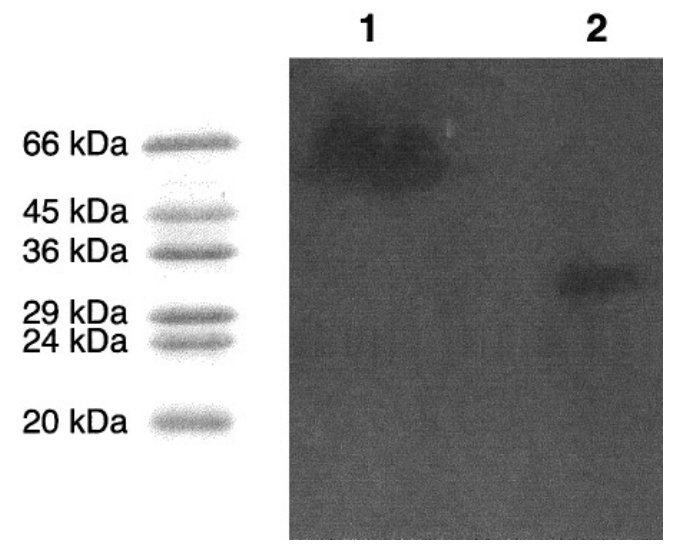

FIG. 7. DNase detection with the SDS-PAGE technique. Lane 1, granule protein extract (30 $\mu \mathrm{g})$; lane 2 , reference DNase I $(0.5 \mu \mathrm{g})$.

on a fluorescent background when gels are incubated in an appropriate buffer and ethidium bromide is added. A commercial 31-kDa DNase I (Sigma, St. Louis, MO) was used as positive control, and protein standards (Dalton Mark III L, Sigma) were used as molecular weight references. When native DNA was incorporated into the gel, one band of approximately $66 \mathrm{kDa}$ appeared (Fig. 7). However, the intensity of the band, and consequently the activity, practically disappeared when denatured DNA (heated at $100^{\circ} \mathrm{C}$ for $10 \mathrm{~min}$ ) was used (data not shown). Therefore, it can be concluded that granules contained a 66-kDa DNase preferentially fragmenting double-strand DNA. I dentical results were obtained with equivalent extracts from five different donors.

DNaseactivity on cytoplasmic granules in monocytes from PBMC incubated in the presence of NMLA. We carried out a series of experiments to determine the DNase activity associated with cytoplasmic granules when PBMC from healthy donors were incubated for 5 days in the absence or presence of $1 \mathrm{mM}$ NMLA, an inhibitor of nitric oxide synthases. After incubation we separated monocytes and analyzed the expression of DNase activity in the granules. Figure 8 shows that the increase in activity observed when cells were incubated with an immunopotentiating agent did not take place, if NMLA was also present in the medium.

We examined also if peptide $\mathrm{Pa} 2$ affected the production of nitrite/nitrate, degradation products reflecting NO synthesis, using for that purpose PBMC from two healthy subjects in separate experiments. In the presence of this peptide (with $0.5 \mathrm{mM}$ L-arginine as exogenous substrate) $10^{5}$ cells gave rise to $8.7 \mathrm{nmol}$ of nitrite/nitrate, the amount released to the medium plus that retained within the cells, after $48 \mathrm{~h}$ of incubation. When the peptide was omitted, nitrite/nitrate produced amounted only to $1.8 \mathrm{nmol}$. Similar results had been obtained with peptide Pal in previous work $(12,25)$. The production of nitrite/nitrate in the presence of $\mathrm{Pa} 2$ markedly decreased ( $2.8 \mathrm{nmol}$ per $10^{5}$ cells) when $1 \mathrm{mM}$ NMLA was present in the incubation medium.

\section{DISCUSSION}

An outstanding feature of apoptosis is DNA fragmentation (26); ther efore, it would be reasonable to assume that DNases are involved in that process $(27,28)$. In this report we describe the existence of a DNase of approximately $66 \mathrm{kDa}$, active at low pH values and calcium-dependent, in mature monocytes (Figs. 2, 3, and 7), similar to that described in $T$ lymphocytes (13). A Ca ${ }^{2+}$-independent DNase, active at low $\mathrm{pH}$ and associated with monocyte granules, has already been described (28). There is also a

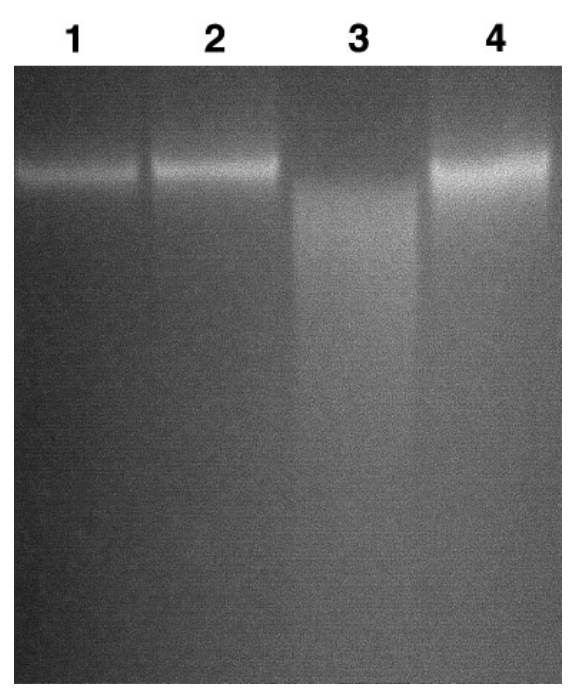

FIG. 8. DNase activity present in granules of monocytes after the incubation of PBMC in the presence of NMLA. In five independent experiments PBMC from healthy donors were incubated in the absence (lane 2) or in the presence of peptide $\mathrm{Pa}$ (30 $\mu \mathrm{g} / 10^{6}$ cells) (lane 3) or in the presence of both peptide and $1 \mathrm{mM}$ NMLA (lane 4). Lane 1 corresponds to DNA incubated without protein extract. 
report (29) on a $\mathrm{Ca}^{2+}$ and $\mathrm{Mg}^{2+}$-dependent DNase in a cell line of murine macrophages which is released to the culture medium; this latter enzyme could be involved in macrophage-mediated cytotoxicity by transferring the enzyme to the target cell, since one of the events after their interaction is DNA fragmentation. The location of the DNase, now described, in secretion granules suggests its possible involvement in cytotoxic processes mediated by the delivery of cytolytic agents by the monocyte to the target cell. A role of this DNase in apoptosis would be consistent with the observation that DNA fragmentation takes place in thymocytes associated with an increase in calcium ions and chelation of intracellular zinc (3032), or in cytotoxic $T$ lymphocytes associated with intracellular acidification (33). It is also known that nitric oxide induces apoptosis in different cells including macrophages (34-36). The DNase activity associated with secretion granules from monocytes, described here, increased in the presence of $\mathrm{NO}$ (Figs. 4-6); when NO production was inhibited, DN ase activity could no longer be detected in secretion granules (Fig. 8). Nitric oxide reacts with a variety of biological molecules such as oxygen, thiols, amines, free radicals, and ferric and ferrous hemoproteins (37). I ntracellular heme proteins are likely to be one of the major targets for NO, including enzymes like guanylyl cyclase $(38,39)$, cyclooxygenase (40), and iNOS (41). The fact that the absence or presence of the reducing agent DTT did not affect the activation of the enzyme by NO (Fig. 6) seems to indicate that it would not be necessary a reduction of disulfide bridges, even in the case that an S-nitrosylation could be involved in the mechanism of activation.

The DNase now described seems to be related to the monocyte subpopulation with a $\mathrm{CD} 14^{+} \mathrm{CD} 16^{+}$ phenotype, characteristic of cytotoxic monocytes rich in secretion granules (2). Apparently, these monocytes derive from the maturation of $\mathrm{CD} 14^{++}$ monocytes (3) which is accompanied by a decrease in the expression of CD14 and an increase in that of CD16. The decrease in CD14 has been associated with the formation of cytotoxic monocytes; thus TGF $-\beta$, which induces the maturation of monocytes, diminishes CD14 expression (42). It has been observed that in infections both an increase in monocyte cytotoxicity and shedding of CD14 molecules take place (43). We have also seen that the $\mathrm{CD} 14^{+} \mathrm{CD} 16^{+}$subpopulation as well as the DNase associated with monocytes increased in patients with autoimmune diseases. This was also the case when PBMC from healthy subjects were activated with immunopotentiating agents (Fig. 1 and Table I). It has been suggested that cytotoxic monocytes could play an important role in the tissue destruction which takes place as part of the autoimmune response (7-9). Nitric oxide could play a relevant role in the fragmentation of DNA caused by an increase in DNase activity in the potentially cytotoxic $\mathrm{CD} 14^{+} \mathrm{CD} 16^{+}$subpopulation; in fact, the presence of iNOS in monocytes from patients with Graves' disease or multiple sclerosis has been described (12, 44), and the expression of this nitric oxide synthase seems to be related to the $\mathrm{CD} 14^{+} \mathrm{CD} 16^{+}$subpopulation (12).

The implication of DNase in the apoptosis of the monocytes themselves cannot be ruled out; the possibility that a transfer of the enzyme from the granules to the cytoplasm and then to the nucleus should not be excluded. We have observed that fresh monocytes from patients with Graves' disease exhibit a high level of apoptosis. This was also the case with monocytes isolated from PBMC from healthy donors after incubation in the presence of peptide Pal (45). It has been described that peptide Pal induces an increase in $\mathrm{NF}-\kappa \mathrm{B}$ binding activity in monocytes (46), and also that NO could provoke the activation of genes responsible for apoptosis through the activation of this nuclear factor (47).

In summary, data presented here show that a DNase was present in granules of monocytes freshly obtained from patients with autoimmune diseases. Data strongly suggest that this enzyme could participate in cytolytic processes in autoimmunity. It could also play some role in the apoptosis of the monocytes themselves, thus preventing or restricting some of the undesirable effects caused by these cells in the autoimmune response.

\section{ACKN O WLEDG MENTS}

The skillful technical assistance of Adela Bezunartea is gratefully acknowledged. R.P. was recipient of a fellowship from Fundación Ramón Areces, Spain. This study is supported by Comisión Interministerial de Ciencia y Tecnología (CICYT), Spain, Grant SAF 97-0233. 


\section{REFERENCES}

1. Ziegler-Heitbrock, H. W. (1989). The biology of the monocyte system. Eur. J . Cell. Biol. 49, 1-12.

2. Passlick, B., Flieger, D., and Ziegler-Heitbrock, H. W. (1989). Identification and characterization of a novel monocyte subpopulation in human peripheral blood. Blood 74, 2527-2534.

3. Ziegler-Heitbrock, H. W., Fingerle, G., Strobel, M., Schraut, W., Stelter, F., Schutt, C., Passlick, B., and Pforte, A. (1993). The novel subset of $\mathrm{CD} 14^{+} / \mathrm{CD} 16^{+}$blood monocytes exhibits features of tissue macrophages. Eur. J . Immunol. 23, 20532058.

4. Bucana, C., Hoyer, L. C., Hobbs, B., Breesman, S., McDaniel, M., and Hanna, M. G., J r. (1976). Morphological evidence for the translocation of lysosomal organelles from cytotoxic macrophages into the cytoplasm of tumor target cells. Cancer Res. 36, 4444- 4458.

5. Martin, J. H., and Edwards. S. W. (1994). Interferon-gamma enhances monocyte cytotoxicity via enhanced reactive oxygen intermediate production. Absence of an effect on macrophage cytotoxicity is due to failure to enhance reactive nitrogen intermediate production. I mmunology 81, 592-597.

6. Porrini, A. M., and Reder, A. T. (1994). IFN- $\gamma$, IFN- $\beta$, and PGE 1 affect monokine secretion: Relevance to monocyte activation in multiple sclerosis. Cell. I mmunol. 157, 428- 438.

7. J iménez-López, A., Olmos-Martínez, J. M., García-Palomo, J . D., De Dios-Martín, B., Pedraz-García, M. J ., and LorenteToledano, F. (1982). Monocyte functional defects in rheumatoid arthritis. F. Allergol. I mmunopathol. Madr. 10, 353-359.

8. Suzuki, S., Mitsunaga, M., Miyoshi, M., Hirakawa, S., Nakagawa, O., Miura, H., and Ofuji, T. (1980). Cytophilic antithyroglobulin antibody and antibody-dependent monocytemediated cytotoxicity in Hashimoto's thyroiditis. J. Clin. Endocrinol. Metab. 51, 446- 453.

9. Thorsteinsson, L., Abrahamsen, T. G., Froland, S. S., and Kass, O. E. (1981). Monocyte cytotoxicity in connective tissue diseases. Correlation with disease groups. Scand. J . Rheumatol. 10, 49-54.

10. Moncada, S., Palmer, R. M., and Higgs, E. A. (1991). Nitric oxide: Physiology, pathophysiology, and pharmacology. Pharmacol. Rev. 43, 109-142.

11. Deakin, A. M., Payne, A. N., Whittle, B. J ., and Moncada, S. (1995). The modulation of IL-6 and TNF-alpha release by nitric oxide following stimulation of $\mathrm{J} 774$ cells with LPS and IFN-gamma. Cytokine 7, 408-416.

12. López-Moratalla, N., González, A., Aymerich, M., LópezZabalza, M. J ., Pío, R., de Castro, P., and Santiago, E. (1997). Monocyte inducible nitric oxide synthase in multiple sclerosis. Regulatory role of NO. Nitric Oxide 1, 95-104.

13. Pío, R., González, A., López-Zabalza, M. J ., Prieto, J ., Santiago, E., and López-Moratalla, N. (1998). Granule associated DNase in T4 and T8 lymphocytes from patients with autoimmune diseases. Biochim. Biophys. Acta 1406, 62-72.
14. López-Moratalla, N., López-Zabalza, M. J ., Subirá, M. L., Borrás-Cuesta, F., Pérez-Mediavilla, L. A., and Santiago, E. (1994). I mmunomodulation induced by synthetic peptides derived from Staphylococcus aureus protein A. Biochim. Biophys. Acta 1221, 153-158.

15. López-Moratalla, N., Migliacio, M., López-Zabalza, M. J., Pérez-Mediavilla, L. A., and Santiago, E. (1994). Activation of human $\mathrm{T}$ helper 1 and DNAase expression in $\mathrm{CD} 4^{+} \mathrm{T}$ cells induced by short immunomodulating peptides. Biochem. Biophys. Res. Commun. 205, 2008-2012.

16. López-Moratalla, N., Ruiz, E., López-Zabalza, M.J ., and Santiago, E. (1996). A common structural motif in immunopotentiating peptides with sequences present in human autoantigens. Elicitation of a response mediated by monocytes and Th1 cells. Biochim. Biophys. Acta 1317, 183-191.

17. Merrifield, R. B. (1963). Solid phase peptide synthesis. I. The synthesis of a tetrapeptide. J. Am. Chem. Soc. 85, 21492154.

18. Atherton, E., Logan, J . C., and Sheppard, R. C. (1981). Peptide synthesis. Part II. Procedures for solid phase synthesis using $\mathrm{N}$-fluorenylmethoxicarbonyl amino acids on polyamide supports. Synthesis of substance $P$ and of acyl carrier protein 65-74 decapeptide. J. Chem. Soc. Perkins Trans. 1, 538-546.

19. Bøyum, A. (1983). Isolation of human blood monocytes with Nycodenz, a new non-ionic iodinated gradient medium. Scand. J . Immunol. 17, 429- 436.

20. Podack, E. R., Young, J. D., and Cohn, Z. A. (1985). I solation and biochemical and functional characterization of perforin 1 from cytolitic T cell granules. Proc. Natl. Acad. Sci. USA 82, 8629- 8633.

21. Gross-Bellard, M., Oudet, P., and Chambon, P. (1973). I solation of high-molecular-weight DNA from mammalian cells. Eur. J . Biochem. 36, 32-38.

22. Laemmli, U. K., and Favre, M. (1973). Maturation of the head of bacteriophage T4. J. Mol. Biol. 80, 575-579.

23. Rosenthal, A. L., and Lacks, S. A. (1977). Nuclease detection in SDS-polyacrylamide gel electrophoresis. Anal. Biochem. 80, 76- 80 .

24. Compton, M. M. (1992). A biochemical hallmark of apoptosis: Internucleosomal degradation of the genome. Cancer Metastasis Rev. 11, 105-119.

25. Pérez-Mediavilla, L. A., López-Zabalza, M. J ., Calonge, M., Montuenga, L., López-Moratalla, N., and Santiago, E. (1995). Inducible nitric oxide synthase in human lymphomononuclear cells activated by synthetic peptides derived from extracellular matrix proteins. FEBS Lett. 357, 121-124.

26. Cohen, J . J ., and Duke, R. C. (1984). Glucocorticoid activation of a calcium-dependent endonuclease in thymocyte nuclei leads to cell death. J . I mmunol. 132, 38-42.

27. Wyllie, A. H. (1980). Glucocorticoid-induced thymocyte apoptosis is associated with endogenous endonuclease activation. Nature 284, 555-556. 
28. Robertis, P. (1990). Development, characterization, and subcellular location of DNase activity in HL-60 cells and monocytes. Blood 75, 976-983.

29. Higashi, N., Nishimura, Y., Higuchi, M., and Osawa, T. (1991). Human monocytes in a long-term culture with interleukin-2 show high tumoricidal activity against various tumor cells. I mmunotherapy 10, 247-255.

30. McCabe, M. J ., J r., J iang, S. A., and Orrenius, S. (1993). Chelation of intracellular zinc triggers apoptosis in mature thymocytes. Lab. Invest. 69, 101-110.

31. J iang, S., Chow, S. C., McCabe, M. J ., J r., and Orrenius, S. (1995). Lack of $\mathrm{Ca}^{2+}$ involvement in thymocyte apoptosis induced by chelation of intracellular $\mathrm{Zn}^{2+}$. Lab. Invest. 73, 111-117.

32. Bellomo, G., Perotti, M., Taddei, F., Mirabelli, F., Finardi, G., Nicotera, P., and Orrenius, S. (1992). Tumor necrosis factor alpha induces apoptosis in mammary adenocarcinoma cells by an increase in intranuclear free $\mathrm{Ca}^{2+}$ concentration and DNA fragmentation. Cancer Res. 52, 1342-1346.

33. Li, J ., and Eastman, A. (1995). Apoptosis in an interleukin2-dependent cytotoxic $T$ lymphocyte cell line is associated with intracellular acidification. Role of the $\mathrm{Na}^{+} / \mathrm{H}^{+}$-antiport. J . Biol. Chem. 270, 3203-3211.

34. Cui, S., Reichner, J . S., Mateo, R. B., and Albina, J . E. (1994). Activated murine macrophages induce apoptosis in tumor cells through nitric oxide-dependent or -independent mechanisms. Cancer Res. 54, 2462-2467.

35. Albina, J . E., Cui, S., Mateo, R. B., and Reichner, J . S. (1993). Nitric oxide-mediated apoptosis in murine peritoneal macrophages. J . Immunol. 150, 5080-5085.

36. Sarih, M., Souvannavong, V., and Adam, A. (1993). Nitric oxide synthase induces macrophage death by apoptosis. Biochem. Biophys. Res. Commun. 191, 503-508.

37. Butler, A. R., and Williams, D. L. (1993). The physiological role of nitric oxide. Chem. Soc. Rev. 22, 233-241.

38. Katsuki, S., Arnold, W., Mittal, C. K., and Murad, F. (1977). Stimulation of guanylate cyclase by sodium nitroprusside, nitroglycerin and nitric oxide in various tissue preparations and comparison to the effects of sodium azide and hydroxylamine. J . Cyclic Nucleotide Res. 3, 23-35.

39. Arnold, W. P., Mittal, C. K., Katsuki, S., and Murad, F. (1977). Nitric oxide activates guanylate cyclase and increases guanosine $3^{\prime}-5^{\prime}$-cyclic monophosphate levels in various tissue preparations. Proc. Natl. Acad. Sci. USA 74, 3203-3207.

40. Salvemini, D., Misko, T. P., Masferrer, J . L., Seibert, K., Currie, M. G., and Needleman, P. (1992). Nitric oxide activates cycl ooxygenase enzymes. Proc. Natl. Acad. Sci. USA 90, $7240-7244$.

41. Griscavage, J . M., Rogers, N. E., Sherman, M. P., and I gnarro L. J . (1993). Inducible nitric oxide synthase from a rat alveolar macrophage cell line is inhibited by nitric oxide. J . I mmunol. 151, 6329- 6337.

42. Hamon, G., Mulloy, R. H., Chen, G., Chow, R., Birkenmaier, C., and Horn, J . K. (1994). Transforming growth factor- $\beta 1$ lowers the CD14 content of monocytes. J . Surg. Res. 57, 574-578.

43. Nockher, W. A., Bergmann, L., and Scherberich, J . E. (1994). Increased soluble CD14 serum levels and altered CD14 expression of peripheral blood monocytes in HIV-infected patients. Clin. Exp. Immunol. 98, 369-374.

44. López-Moratalla, N., Calleja, A., González, A., PérezMediavilla, L. A., Aymerich, M. S., Burrel, M. A., and Santiago, E. (1996). Inducible nitric oxide synthase in monocytes from patients with Graves' disease. Biochem. Biophys. Res. Commun. 226, 723-729.

45. Santiago, E., López-Zabalza, M. J., Osés, J., and Pío, R. (1998). Apoptotic and cytotoxic monocytes in autoimmunity. Role of NO. In The Biology of Nitric Oxide (Moncada, S., Toda, N., Maeda, H., and Higgs, E. A., Ed.), Vol. 6. Portland Press, London (in press).

46. López-Zabalza, M. J ., Martínez-Lausin, S., BengoecheaAlonso, M. T., López-Moratalla, N., González, A., and Santiago, E. (1997). Signaling pathway triggered by a short immunomodulating peptide on human monocytes. Arch. Biochem. Biophys. 338, 136-142.

47. Buttke, T. M., and Sandstrom, P. A. (1994). Oxidative stress as a mediator of apoptosis. Immunol. Today 15, 7-10. 